\title{
Study of polymorphisms in tir, eae and tccP2 genes in enterohaemorrhagic and enteropathogenic Escherichia coli of serogroup $\mathrm{O} 26$
}

\author{
Marjorie Bardiau, Sabrina Labrozzo and Jacques G Mainil*
}

\begin{abstract}
Background: Enteropathogenic (EPEC) and enterohaemorrhagic (EHEC) Escherichia coli are responsible for food poisoning (enteritis and enterotoxaemia) in humans in developed countries. Cattle are considered to be an important reservoir of EHEC and EPEC strains for humans. Moreover, some of the strains, belonging to the O26, 0111, 0118 serogroups, for example, are also responsible for digestive disorders in calves. The Translocated intimin receptor (Tir), the intimin (Eae) and the Tir-cytoskeleton coupling protein (TccP) represent three virulence factors implicated in the intimate attachment of the bacteria to the eukaryotic cell. Major variants have already been described for these genes among the different serogroups but minor variations have not often been studied. In this study, we examined the polymorphisms of the tir, eae and tCCP2 genes of O26 strains (EPEC and EHEC isolated from bovines and from humans) with the aim to determine whether these polymorphisms are host specific or not.

Results: Of the 70 tested strains, 10 strains (14\% of the strains) presented one or several polymorphisms in the tir and eae genes, which have never previously been described. Concerning tccP2 detection, 47 of the 70 strains (67\% of the strains) were found to be positive for this gene. Most of the strains were found to possess tccP2 variants described in strains of serogroup O26. Nevertheless, three strains had $t c c P 2$ genes respectively described in strains of serogroup 0111, O103 and O55. Moreover, none of the polymorphisms was statistically specific to the bovine or the human isolates. Nevertheless, the two major variants of tccP2 were statistically associated with the pathotype (EPEC or EHEC).

Conclusions: In conclusion, tir and eae gene polymorphisms were found not to be numerous and not to be predominantly synonymous. Moreover, no difference was observed between human and bovine strains regarding the presence of polymorphisms. Finally, some tccP2 variants appeared to be pathotype specific. Further investigations need to be performed on a larger number of strains in order to confirm this specificity.
\end{abstract}

\section{Background}

Enteropathogenic (EPEC) and enterohaemorrhagic (EHEC) Escherichia coli represent two important classes of enteric pathogens. EPEC strains belonging to different serogroup (e.g. 026, 055, 086, 0111, O128) are a major cause of infant diarrhoea in many countries and are also associated with diarrhoea in most domestic animal species $[1,2]$. These strains can be classified into two groups: typical-EPEC strains (t-EPEC), harbouring a specific plasmid named EPEC Adherence Factor (EAF plasmid), and atypical-EPEC strains (a-EPEC), which do not

\footnotetext{
* Correspondence: jg.mainil@ulg.ac.be

Bacteriology, Department of Infectious and Parasitic Diseases, Veterinary Faculty, University of Liège, Liège B4000, Belgium
}

carry this specific EAF plasmid. EHEC strains have been responsible for individual cases, and small to large outbreaks in developed countries [3-8]. O157:H7 is the main serotype responsible for human illness in several countries. Nevertheless non-O157 serogroups can also be associated frequently with severe disease in humans and O26 serogroup represent the second more important serogroup in Europe [9-11]. Syndromes caused in humans are diverse: undifferentiated diarrhoea, haemorrhagic colitis (HC), haemolytic uremic syndrome (HUS) and thrombotic thrombocytopaenic purpura (TP) [12]. Transmission often occurs via consumption of foodstuffs contaminated by faeces from ruminants (mainly cattle), which can be asymptomatic healthy carriers $[13,14]$.
C Biomed Central

(c) 2011 Bardiau et al; licensee BioMed Central Ltd. This is an Open Access article distributed under the terms of the Creative Commons Attribution License (http://creativecommons.org/licenses/by/2.0), which permits unrestricted use, distribution, and reproduction in any medium, provided the original work is properly cited. 
Nevertheless, several serogroups of EHEC strains (e.g. O26, O111, O118) are also associated with diarrhoea in calves [15-18].

EPEC and EHEC share four stages in their pathogenicity: (1) colonisation of the intestine by specific adhesins, (2) translocation of a signal into the enterocyte by the type III secretion system (T3SS) of the bacteria and integration of the Translocated intimin receptor (Tir) into the host cell membrane, (3) intimate adhesion of bacteria to eukaryote cells by specific adhesins (intimins) that bind to Tir, and (4) actin polymerization after Tir phosphorylation. These four stages allow the bacteria to produce a specific lesion called an "attaching and effacing (A/E) lesion" [1]. Furthermore, as well as using the Tir phosphorylation pathway, some strains (EPEC 2 strains and the vast majority of non-O157 EHEC strains) are able to utilize the T3SS effector TccP2 (Tir-cytoskeleton coupling protein 2) to trigger actin polymerization, which leads to the formation of a pedestal characteristic of the A/E lesion [19].

Sequence variations in the Tir receptor-, intimin adhesin- and TccP2 effector-encoding genes (tir, eae and tccp2) have been described between EHEC and EPEC strains, and these can lead to major or minor polymorphisms (variants) of the encoded proteins [20-24]. Major variants of Tir and intimin are related, to some extent, to the serogroups of the EHEC and EPEC strains, whereas minor variants can exist within a serogroup for the same major variant, although these have not often been defined [25,26]. EHEC and EPEC strains belonging to the $\mathrm{O} 26$ serogroup classically produce the beta major variant of Tir and intimin, but their minor variants have not been studied [26,27]. Only two major variants of TccP have been described that are related to the pathotype of the strain [19]. EHEC and EPEC strains of $\mathrm{O} 26$ serogroup produce the TccP2 variant with six minor variants identified [23,24].

The purposes of this study were (1) to investigate the polymorphism of the tir, eae and tccP2 genes between O26 EPEC and EHEC strains isolated from bovines and from humans; and (2) to determine whether these polymorphisms are specific to bovine or human strains.

\section{Results}

Detection of tir, eae and tccP2 genes

All the tested strains of serogroup O26 were found to possess $\beta$ type eae and tir genes. Moreover, of the 70 tested strains, 10 strains (14\% of the strains) presented one or several polymorphisms in these two genes. None of the polymorphic strains possessed polymorphism in both eae and tir genes. Concerning tccP2 detection, 47 of the 70 strains (67\% of the strains) were positive for this gene. Most of the strains possessed tccP2 variants described in strains of serogroup O26. Three strains had
tccP2 genes respectively described in strains of serogroup O111, O103 and O55.

\section{Polymorphisms in the eae gene}

For the eae gene, four polymorphisms were detected in nucleotide positions 255 ( $\mathrm{G}>\mathrm{A}$ ), 1859 (C > T), 2415 (A $>\mathrm{T})$ and $2772(\mathrm{C}>\mathrm{T})$ in eae $\beta$ gene reference strain 14I3, (accession number FJ609815) and five unique eae $\beta$ genotypes were defined (Table 1 ). The "classical" genotype (strain 14I3 sequence) was represented by $93 \%$ (65 $+/ 70$ ) of the strains and the four other genotypes were represented by only one or two strains. Even though there was no statistical significance $(p=0.078)$, all the strains that presented polymorphism were bovine EPECs. One polymorphism was non-synonymous and gave one genotype different in the amino-acid (AA) sequence: valine was coded in place of alanine in AA position 620. This AA is situated in the D0 Ig-like domain.

\section{Polymorphisms in the tir gene}

For the tir gene, five polymorphisms were detected in nucleotide positions $133(\mathrm{~T}>\mathrm{G}$ ), 571 (insertion of GATACAAAG), 939 (G > A), 1080 (G > T) and 1302 $(\mathrm{C}>\mathrm{T})$ in tir $\beta$ genes reference strain 95ZG1 (accession number AF070068) and four unique tir $\beta$ genotypes were defined (Table 2). Interestingly, one polymorphism (position 939) was found to be present in all the strains. One genotype was represented by $93 \%(65+/ 70)$ of the strains, and the other three genotypes were represented by only one or two strains. Two polymorphisms were found to be non-synonymous and gave three different genotypes in the AA sequences: for the first polymorphism, serine was coded in place of alanine in AA position 45; for the second polymorphism, three AA (TKE) were inserted into AA position 191. These two polymorphisms were situated in the N-terminal part of the gene. Nevertheless, when we compared polymorphisms regarding the host and the pathotype (EPEC or EHEC), none was found to be specific to the bovine or the human isolates $(\mathrm{p}<0.05)$ or to EPEC or EHEC pathotype.

\section{Polymorphisms in the tccP2 gene}

For the tccP2 gene, seven genotypes (Table 3) were detected in the collection. All had been previously described $[23,24]$. The $t c c P 2$ variant described in reference strain 11368 (accession number AB253564) was found to be present in $34 \%(24+/ 70)$ of the strains. The tccP2 variant described in reference strain EC38/99 (accession number AB275131) was present in 17\% (12 $+/ 70)$ of the strains. $t c c P 2$ variants described in reference strains 12009 and CB00225 (accession number AB253581 and AB275122 respectively) were both 
Table 1 eae $\beta$ gene polymorphism (aa: amino acid, A: alanine, V: valine)

\begin{tabular}{|c|c|c|c|c|c|c|c|}
\hline & \multicolumn{3}{|c|}{ Number of strains } & \multirow{2}{*}{$\begin{array}{l}\text { Polymorphism } 1 \\
\text { (S) } 255 \mathrm{G}=>\mathrm{A}\end{array}$} & \multirow{2}{*}{$\begin{array}{c}\text { Polymorphism } 2 \\
\text { (NS) } 1859 \mathrm{C}=>\mathrm{T} \\
620 \text { aa: } A=>V\end{array}$} & \multirow{2}{*}{$\begin{array}{l}\text { Polymorphism } 3 \\
\text { (S) } 2415 \mathrm{~A}=>\mathrm{T}\end{array}$} & \multirow{2}{*}{$\begin{array}{l}\text { Polymorphism } 4 \\
\text { (S) } 2772 \mathrm{C}=>\mathrm{T}\end{array}$} \\
\hline & Human & Bovine & & & & & \\
\hline & 0 & 1 & Genotype 1 & + & - & - & - \\
\hline & 0 & 2 & Genotype 2 & + & + & - & - \\
\hline & 0 & 1 & Genotype 3 & - & - & + & - \\
\hline & 0 & 1 & Genotype 4 & - & - & - & + \\
\hline & 28 & 37 & Genotype 5 & - & - & - & - \\
\hline Total & 28 & 42 & & & & & \\
\hline
\end{tabular}

present in $6 \%(4+/ 70)$ of the strains. Three tccP2 variants described in reference strains ED411, ED71 and 5905 (accession number AB253567, AB253576 and AB356001 respectively) were represented by only one strain each. None of the variants was found to be specific to the bovine or the human isolates $(p<0.05)$. Nevertheless, the two major variants were statistically associated with the pathotype $(\mathrm{p}<0.01)$ : the $t c c P 2$ gene AB275131 was statistically associated with the EPEC strains in comparison with the EHEC strains and the tccP2 gene AB253564 was statistically associated with the EHEC strains in comparison with the EPEC strains.

\section{Discussion}

The Tir receptor (encoded by the tir gene) and the intimin adhesin (encoded by the eae gene) are both implicated in the adherence of the EPEC and EHEC strains to eukaryotic cells via the binding of the intimin to the Tir receptor (previously translocated to the host cell). The A/E lesion is then produced and is characterized by the loss of microvilli and intimate attachment of the bacteria to the host cell. Moreover, non-O157 strains can utilize TccP2, as well as Tir, to trigger actin polymerization during the production of the A/E lesion [19]. There are variations in the eae, tir and tccP2 gene sequence and many variants have been described
[20-22]. Nevertheless small variations (polymorphisms) inside the same variants have not often been described. In 2007, Bono et al.[25] studied the polymorphism of tir and eae genes in $\mathrm{O} 157$ strains and associated two tir polymorphisms with the isolate source (bovine or human). With this in mind, we performed the present work to study the polymorphism of the tir, eae and tccP2 genes existing in O26 EPEC and EHEC strains isolated from bovines and from humans with a view to determinate whether these polymorphisms are specific to bovine or human strains in the $\mathrm{O} 26$ serogroup.

$t c c P 2$ variants were found to be present in $67.1 \%$ of the tested strains. This is not surprising regarding the results obtained by Ooka et al. and Ogura et al., who respectively found the $t c c P 2$ gene in $82.3 \%$ of $\mathrm{O} 26$ aEPEC strains and in $71.4 \%$ of O26 EHEC strains [23,24]. It is possible that the negative isolates use only the Tir phosphorylation pathway or that they utilize another unknown pathway. Moreover, the distribution of $t c c P 2$ variants appears to be specific to the pathotype. In our study, tccP2 variant (accession number AB253564) originally described in the O26 EHEC 11368 reference strain was found to be statistically associated to EHEC strains in our study and $t c c P 2$ variant (accession number AB275131) originally described in O26 a-EPEC EC38/99 reference strain was found to be statistically associated

Table 2 tir $\beta$ gene polymorphism (aa: amino acid, A: alanine, S: serine, T: threonine, K: lysine, E: glutamic acid)

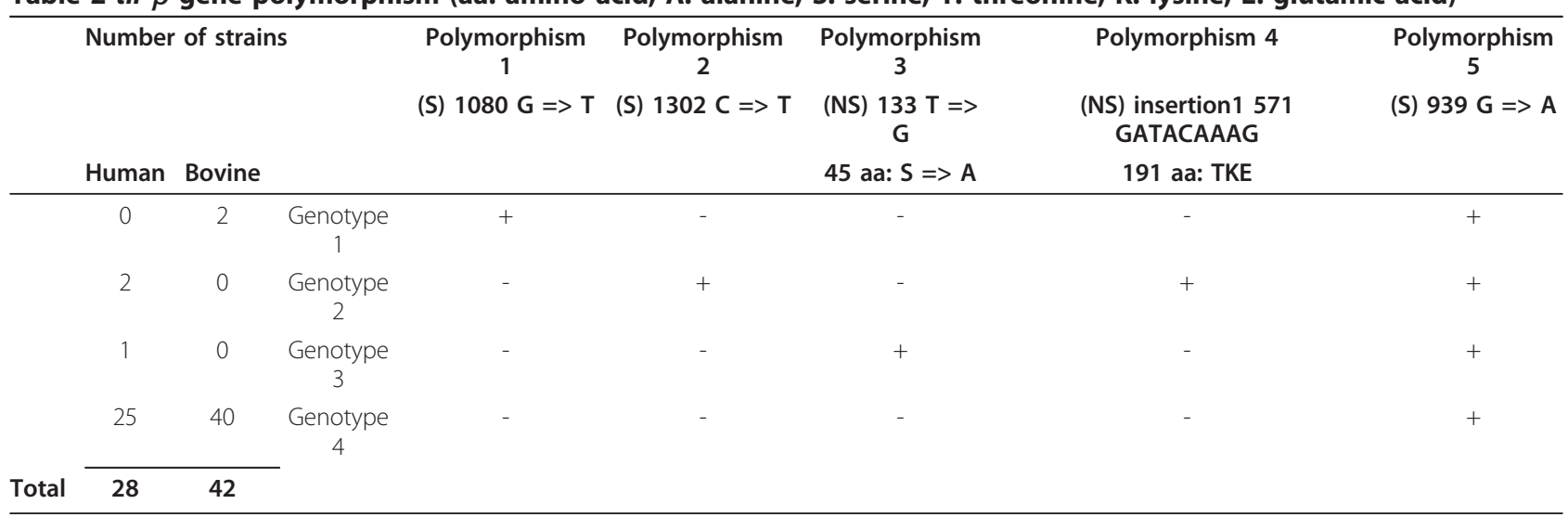




\begin{tabular}{|c|c|c|c|c|c|}
\hline \multirow{2}{*}{$\begin{array}{l}\text { Accession number of } t c c P 2 \text { variant } \\
\text { (variant described in serogroup) }\end{array}$} & \multicolumn{5}{|c|}{ Positive isolates in } \\
\hline & Total & EHEC & EPEC & Bovine & Human \\
\hline AB253564 (O26) & $24+/ 70$ & $21+/ 44$ & $3+/ 26$ & $17+/ 42$ & $7+/ 28$ \\
\hline AB275131 (026) & $12+/ 70$ & $2+/ 44$ & $10+/ 26$ & $9+/ 42$ & $3+/ 28$ \\
\hline AB275122 (O26) & $4+/ 70$ & $0+/ 44$ & $4+/ 26$ & $4+/ 42$ & $0+/ 28$ \\
\hline AB253581 (0013) & $4+/ 70$ & $4+/ 44$ & $0+/ 26$ & $0+/ 42$ & $4+/ 28$ \\
\hline AB253567 (O26) & $1+/ 70$ & $1+/ 44$ & $0+/ 26$ & $0+/ 42$ & $1+/ 28$ \\
\hline AB253576 (O55) & $1+/ 70$ & $1+/ 44$ & $0+/ 26$ & $1+/ 42$ & $0+/ 28$ \\
\hline АВ356001 (0111) & $1+/ 70$ & $0+/ 44$ & $1+/ 26$ & $0+/ 42$ & $1+/ 28$ \\
\hline
\end{tabular}

to a-EPEC strains. However, further studies need to be performed in order to confirm this pathotype specificity. If this association appears to be confirmed, it could be used as a tool to study, among other things, O26 EPEC strains (isolated from patients or from calves) in order to determine if these strains are "real" O26 EPEC strains or O26 EHEC strains that have lost stx genes[28].

In comparison with O157 strains, O26 strains do not possess a large number of polymorphisms in the $t i r$ gene (only four different genotypes were revealed by our study and the major one was represented by $92.8 \%$ of the strains in comparison with ten different genotypes revealed by the study of Bono et al. with the major one represented by $68.6 \%)$. By contrast, eae polymorphisms are, in both studies, very limited. Bono et al. explained this difference in polymorphism frequency (between eae and tir genes) among $\mathrm{O} 157$ strains by the fact that both genes have evolved under a different kind of selective pressure. The difference in tir polymorphism frequency between $\mathrm{O} 157$ and $\mathrm{O} 26$ strains could also be explained by a different kind of selective pressure between both serogroups. Currently, we know that O157 EHEC strains and O26 EHEC and EPEC strains possess two different actin signalling pathways [19]. The O157 EHEC strains use only the TccP adaptor to induce actin polymerization and the O26 EHEC and EPEC strains can use two other pathways: the TccP2 adaptor and the phosphorylation of Y474 Tir residue. Therefore, it is not surprising that tir polymorphisms are more frequent in $\mathrm{O} 157$ EHEC strains than in O26 EHEC and EPEC strains.

Furthermore, the polymorphisms in tir and eae genes revealed by our study are mainly synonymous. For the eae gene, only one polymorphism was found to be non-synonymous (valine is coded in place of alanine in position 620) and this is situated in the D0 Ig-like domain. This polymorphism is not surprising and the consequences on the protein structure are probably nil for two reasons: firstly, in the eae $\zeta$ gene, valine is situated at this position and secondly, D0 is a divergent region that is not entirely conserved [29]. For the tir gene, two polymorphisms were found here to be non-synonymous and these are located near the amino terminus of Tir. This region is normally situated in the host cytosol after Tir translocation and is probably implicated in pedestral length, pedestral efficiency and translocation in the host cell [30].

Finally, concerning host specificity, in contrast to O157 strains [25], our study revealed that tir and eae polymorphisms are not associated with the host (human or bovine). In comparison to O157 strains, which seem to be host classifiable using nucleotide polymorphisms [31,32], we were unable to distinguish O26 strains. Several studies have suggested that $\mathrm{O} 157$ strains can be separated into two distinct lineages (lineages I and II), which appear to have distinct ecological characteristics, and which are associated with the host [33-36].

\section{Conclusions}

In conclusion, tir and eae genes of O26 EHEC and EPEC strains are well conserved. Polymorphisms are not numerous or predominantly synonymous. Moreover, no difference was observed between human and bovine strains regarding the presence of polymorphisms. Finally, tccP2 variants appear to be pathotype specific. Further investigations need to be performed on a larger number of strains in order to confirm this specificity.

\section{Methods}

\section{Bacterial strains}

A total of 70 EHEC $(n=44)$ and EPEC $(n=26)$ strains of serogroup O26 isolated from bovine $(n=42)$ and humans $(\mathrm{n}=28)$ and from diverse countries (USA, Ireland, Belgium, France, Japan and Brazil) were studied. Most of the strains had been described previously $[37,38]$ and their pathotype (EPEC or EHEC) and serotype O26:H11 had been confirmed by PCR for stx1, stx2, eae, wzx-wzy $y_{\mathrm{O} 26}$ and $f l i C_{H 11}$ genes [39-41].

\section{$\mathrm{PCR}$ reaction}

A $2941 \mathrm{pb}$ segment of the eae gene, a $1559 \mathrm{pb}$ segment of the tir gene and a $753 \mathrm{pb}$ segment of $t c c P 2$ gene were amplified by PCR, using respectively four pairs of primers, two pairs of primers and one pair of primers. All 
the primers used in this study and all the annealing temperatures are listed in Table 4. For PCR reactions, the following mixture was used: $1 \mathrm{U}$ of Taq DNA polymerase (New England Biolabs, USA), $5 \mu \mathrm{l}$ of $2 \mathrm{mM}$ deoxynucleoside triphosphates, $5 \mu \mathrm{l}$ of $10 \mathrm{X}$ ThermoPol Reaction Buffer $\left(20 \mathrm{mM}\right.$ Tris- $\mathrm{HCl}\left(\mathrm{pH} 8.8,25^{\circ} \mathrm{C}\right), 10$ $\mathrm{mM} \mathrm{KCl}, 10 \mathrm{mM}\left(\mathrm{NH}_{4}\right)_{2} \mathrm{SO}_{4}, 2 \mathrm{mM} \mathrm{MgSO}{ }_{4}, 0.1 \%$ Triton $\mathrm{X}-100), 5 \mu \mathrm{l}$ of each primer $(10 \mu \mathrm{M})$, and $3 \mu \mathrm{l}$ of a DNA template in a total volume of $50 \mu$ l.

\section{DNA sequencing}

The DNA fragments amplified were purified using the NucleoSpin Extract II kit (Macherey-Nagel, Germany) according to the manufacturer's instructions. Sequencing of the two DNA strands was performed by the dideoxynucleotide triphosphate chain termination method with a 3730 ABI capillary sequencer and a BigDye Terminator kit version 3.1 (Applied Biosystems, USA) at the GIGA (Groupe Interdisciplinaire de Génoprotéomique Appliquée, Belgium). Sequence analysis was performed using Vector NTI 10.1.1 (Invitrogen, USA). DNA sequencing was performed three times.

\section{Statistical analysis}

A Fisher's exact test was performed to assess statistical differences.

Table 4 Primers used in this study $(R=A+G, K=T+G, Y=C+T)$

\begin{tabular}{|c|c|c|c|c|c|}
\hline Primer name & Sequence $\left(5^{\prime}\right.$ to $\left.3^{\prime}\right)$ & Target gene & Annealing temp. $\left({ }^{\circ} \mathrm{C}\right)$ & Amplicon size (bp) & Reference \\
\hline B52 & AGGCTTCGTCACAGTTG & eaeA & 50 & 570 & [39] \\
\hline B53 & CCATCGTCACCAGAGGA & & & & \\
\hline B54 & AGAGCGATGTTACGGTTTG & $s t \times 1$ & 50 & 388 & [39] \\
\hline B55 & TTGCCCCCAGAGTGGATG & & & & \\
\hline B56 & TGGGTTITTCTTCGGTATC & $s t \times 2$ & 50 & 807 & [39] \\
\hline B57 & GACATTCTGGTTGACTCTCTT & & & & \\
\hline wzx-wzyO26-F & AAATTAGAAGCGCGTTCATC & $w Z X_{O 26}$ & 56 & 596 & [41] \\
\hline wzx-wzyO26-R & CCCAGCAAGCCAATTATGACT & & & & \\
\hline fliC-H11-F & ACTGTTAACGTAGATAGC & $\mathrm{fliC}_{\mathrm{H11}}$ & 56 & 224 & [41] \\
\hline fliC-H11-R & TCAATTTCTGCAGAATATAC & & & & \\
\hline B139 & CRCCKCCAYTACCTTCACA & $\operatorname{tir} \beta$ & 53 & 560 & [27] \\
\hline B140 & GATTITCCCTCGCCACTA & & & & \\
\hline $\operatorname{tir}(591-1617)-F$ & TCCAAATAGTGGCGAGGGAA & $\operatorname{tir} \beta$ & 54 & 1026 & This study \\
\hline $\operatorname{tir}(591-1617)-R$ & TTAAACGAAACGTGCGGGTC & & & & \\
\hline B73 & TACTGAGATTAAGGCTGATAA & eae $\beta$ & 50 & 520 & {$[27]$} \\
\hline B137 & TGTATGTCGCACTCTGATT & & & & \\
\hline eae(37-1142)-F & CGGCACAAGCATAAGCTAAA & eae $\beta$ & 51 & 1105 & This study \\
\hline eae(37-1142)-R & AGTTACACCAACGGTCGCC & & & & \\
\hline eae(1001-2046)-F & TCCGCTITAATGGCTATTTACC & eae $\beta$ & 50 & 1045 & This study \\
\hline eae(1001-2046)-R & TGCCTTCGCTGTTGTITAT & & & & \\
\hline eae(2319-2972)-F & GGCTCTGCAAAGAACTGGTT & eae $\beta$ & 50 & 653 & This study \\
\hline eae(2319-2972)-R & AGTCTCTATCAAACAAGGATACACG & & & & \\
\hline tccP2-F & ATGATAAATAGCATTAATTCTTT & tCCP2 & 56 & 753 & [24] \\
\hline tccP2-R & TCACGAGCGCTTAGATGTATTAAT & & & & \\
\hline
\end{tabular}




\section{Acknowledgements}

Marjorie Bardiau is a PhD fellow of the "Fonds pour la formation à la Recherche dans I'Industrie et dans l'Agriculture" (FRIA). This study was funded by the Federal Public Service of Health, Food Chain Safety and Environment (contract RF 6172), by grants "Crédits aux chercheurs" FNRS (Fonds de Recherche Scientifique), $n^{\circ} 1642$ and $n^{\circ} 1363$ and by the European Network of Excellence EADGENE (European Animal Disease Genomics Network of Excellence for Animal Health and Food Safety) for the gene sequencing.

\section{Authors' contributions}

$\mathrm{MB}$ conceived of the study, carried out the sequence alignment and drafted the manuscript. SL carried out the PCR reactions. JGM participated in the design and coordination of the study and helped to draft the manuscript. All authors read and approved the final manuscript.

Received: 20 December 2010 Accepted: 30 May 2011

Published: 30 May 2011

\section{References}

1. Chen HD, Frankel G: Enteropathogenic Escherichia coli: unravelling pathogenesis. FEMS Microbiol Rev 2005, 29:83-98.

2. China B, Pirson V, Mainil J: Prevalence and molecular typing of attaching and effacing Escherichia coli among calf populations in Belgium. Vet Microbiol 1998, 63:249-259.

3. Wells JG, Davis BR, Wachsmuth IK, Riley LW, Remis RS, Sokolow R, Morris GK: Laboratory investigation of hemorrhagic colitis outbreaks associated with a rare Escherichia coli serotype. J Clin Microbiol 1983, 18:512-520.

4. Miyajima Y, Takahashi M, Eguchi H, Honma M, Tanahashi S, Matui Y, Kobayashi G, Tanaka M, Higuchi T, Takeuchi Y: Outbreak of Enterohemorrhagic Escherichia coli 026 in Niigata City, Japan. Jpn J Infect Dis 2007, 60:238-239.

5. Sonoda C, Tagami A, Nagatomo D, Yamada S, Fuchiwaki R, Haruyama M, Nakamura Y, Kawano K, Okada M, Shioyama Y, et al: An enterohemorrhagic Escherichia coli $\mathrm{O} 26$ outbreak at a nursery school in Miyazaki, Japan. Jpn J Infect Dis 2008, 61:92-93.

6. Stirling A, McCartney G, Ahmed S, Cowden J: An outbreak of Escherichia coli 0157 phage type 2 infection in Paisley, Scotland. Euro Surveill 2007, 12:E070823 070821.

7. Soderstrom A, Osterberg $P$, Lindqvist A, Jonsson B, Lindberg A, Blide Ulander S, Welinder-Olsson C, Lofdahl S, Kaijser B, De Jong B, et al: A large Escherichia coli 0157 outbreak in Sweden associated with locally produced lettuce. Foodborne Pathog Dis 2008, 5:339-349.

8. Conedera G, Mattiazzi E, Russo F, Chiesa E, Scorzato I, Grandesso S, Bessegato A, Fioravanti A, Caprioli A: A family outbreak of Escherichia coli 0157 haemorrhagic colitis caused by pork meat salami. Epidemiol Infect 2007, 135:311-314.

9. Bettelheim KA: The non-0157 shiga-toxigenic (verocytotoxigenic) Escherichia coli; under-rated pathogens. Crit Rev Microbiol 2007, 33:67-87.

10. Bielaszewska M, Zhang W, Mellmann A, Karch H: Enterohaemorrhagic Escherichia coli O26:H11/H-: a human pathogen in emergence. Berl Munch Tierarztl Wochenschr 2007, 120:279-287.

11. Zimmerhackl LB, Rosales A, Hofer J, Riedl M, Jungraithmayr T, Mellmann A, Bielaszewska M, Karch H: Enterohemorrhagic Escherichia coli O26:H11Associated Hemolytic Uremic Syndrome: Bacteriology and Clinical Presentation. Semin Thromb Hemost 2010, 36:586-593.

12. Raffaelli RM, Paladini M, Hanson H, Kornstein L, Agasan A, Slavinski S, Weiss D, Fennelly GJ, Flynn JT: Child care-associated outbreak of Escherichia coli 0157:H7 and hemolytic uremic syndrome. Pediatr Infect Dis J 2007, 26:951-953.

13. Caprioli A, Morabito S, Brugère H, Oswald E: Enterohaemorrhagic Escherichia coli: emerging issues on virulence and modes of transmission. Vet Res 2005, 36:289-311.

14. Erickson MC, Doyle MP: Food as a vehicle for transmission of Shiga toxinproducing Escherichia coli. J Food Prot 2007, 70:2426-2449.

15. Mainil JG, Daube G: Verotoxigenic Escherichia coli from animals, humans and foods: who's who? J Appl Microbiol 2005, 98:1332-1344.

16. Wieler LH, Vieler E, Erpenstein C, Schlapp T, Steinruck H, Bauerfeind R, Byomi A, Baljer G: Shiga toxin-producing Escherichia coli strains from bovines: association of adhesion with carriage of eae and other genes. $J$ Clin Microbiol 1996, 34:2980-2984.
17. Hornitzky MA, Mercieca K, Bettelheim KA, Djordjevic SP: Bovine feces from animals with gastrointestinal infections are a source of serologically diverse atypical enteropathogenic Escherichia coli and Shiga toxinproducing E. coli strains that commonly possess intimin. Appl Environ Microbiol 2005, 71:3405-3412.

18. Moxley RA, Smith DR: Attaching-effacing Escherichia coli infections in Cattle. Vet Clin North Am Food Anim Pract 2010, 26:29-56, table of contents.

19. Frankel G, Phillips AD: Attaching effacing Escherichia coli and paradigms of Tir-triggered actin polymerization: getting off the pedestal. Cell Microbiol 2008, 10:549-556.

20. Lacher DW, Steinsland H, Whittam TS: Allelic subtyping of the intimin locus (eae) of pathogenic Escherichia coli by fluorescent RFLP. FEMS Microbiol Lett 2006, 261:80-87.

21. Blanco M, Blanco JE, Dahbi G, Alonso MP, Mora A, Coira MA, Madrid C, Juarez A, Bernardez MI, Gonzalez EA, Blanco J: Identification of two new intimin types in atypical enteropathogenic Escherichia coli. Int Microbiol 2006, 9:103-110.

22. Blanco M, Blanco JE, Dahbi G, Mora A, Alonso MP, Varela G, Gadea MP, Schelotto F, Gonzalez EA, Blanco J: Typing of intimin (eae) genes from enteropathogenic Escherichia coli (EPEC) isolated from children with diarrhoea in Montevideo, Uruguay: identification of two novel intimin variants (muB and xiR/beta2B). J Med Microbiol 2006, 55:1165-1174.

23. Ogura Y, Ooka T, Whale A, Garmendia J, Beutin L, Tennant S, Krause G, Morabito S, Chinen I, Tobe T, et al: TccP2 of O157:H7 and non-O157 enterohemorrhagic Escherichia coli (EHEC): challenging the dogma of EHEC-induced actin polymerization. Infect Immun 2007, 75:604-612.

24. Ooka T, Vieira MA, Ogura Y, Beutin L, La Ragione R, van Diemen PM, Stevens MP, Aktan I, Cawthraw S, Best A, et al: Characterization of tccP2 carried by atypical enteropathogenic Escherichia coli. FEMS Microbiol Lett 2007, 271:126-135.

25. Bono JL, Keen JE, Clawson ML, Durso LM, Heaton MP, Laegreid WW: Association of Escherichia coli 0157:H7 tir polymorphisms with human infection. BMC Infect Dis 2007, 7:98

26. Oswald E, Schmidt H, Morabito S, Karch H, Marches O, Caprioli A: Typing of intimin genes in human and animal enterohemorrhagic and enteropathogenic Escherichia coli: characterization of a new intimin variant. Infect Immun 2000, 68:64-71.

27. China B, Goffaux F, Pirson V, Mainil J: Comparison of eae, tir, espA and espB genes of bovine and human attaching and effacing Escherichia coli by multiplex polymerase chain reaction. FEMS Microbiol Lett 1999, 178:177-182.

28. Bielaszewska M, Prager R, Kock R, Mellmann A, Zhang W, Tschape H, Tarr PI, Karch $\mathrm{H}$ : Shiga toxin gene loss and transfer in vitro and in vivo during enterohemorrhagic Escherichia coli O26 infection in humans. Appl Environ Microbiol 2007, 73:3144-3150.

29. Tarr CL, Whittam TS: Molecular evolution of the intimin gene in 0111 clones of pathogenic Escherichia coli. J Bacteriol 2002, 184:479-487.

30. Campellone KG, Brady MJ, Alamares JG, Rowe DC, Skehan BM, Tipper DJ, Leong JM: Enterohaemorrhagic Escherichia coli Tir requires a C-terminal 12-residue peptide to initiate EspF-mediated actin assembly and harbours $\mathrm{N}$-terminal sequences that influence pedestal length. Cell Microbiol 2006, 8:1488-1503.

31. Clawson ML, Keen JE, Smith TP, Durso LM, McDaneld TG, Mandrell RE, Davis MA, Bono JL: Phylogenetic classification of Escherichia coli 0157:H7 strains of human and bovine origin using a novel set of nucleotide polymorphisms. Genome Biol 2009, 10:R56.

32. Whitworth J, Zhang Y, Bono J, Pleydell E, French N, Besser T: Diverse genetic markers concordantly identify bovine origin Escherichia coli 0157 genotypes underrepresented in human disease. Appl Environ Microbiol 2010, 76:361-365.

33. Dowd SE, Ishizaki H: Microarray based comparison of two Escherichia coli 0157:H7 lineages. BMC Microbiol 2006, 6:30.

34. Kim J, Nietfeldt J, Ju J, Wise J, Fegan N, Desmarchelier P, Benson AK: Ancestral divergence, genome diversification, and phylogeographic variation in subpopulations of sorbitol-negative, beta-glucuronidasenegative enterohemorrhagic Escherichia coli O157. J Bacteriol 2001, 183:6885-6897.

35. Steele M, Ziebell K, Zhang Y, Benson A, Konczy P, Johnson R, Gannon V: Identification of Escherichia coli 0157:H7 genomic regions conserved in strains with a genotype associated with human infection. Appl Environ Microbiol 2007, 73:22-31. 
36. Zhang Y, Laing C, Steele M, Ziebell K, Johnson R, Benson AK, Taboada E, Gannon VP: Genome evolution in major Escherichia coli 0157:H7 lineages. BMC Genomics 2007, 8:121.

37. Szalo IM, Taminiau B, Goffaux F, Pirson V, McCappin J, Ball HJ, Mainil JG: 2F3 monoclonal antibody recognizes the $\mathrm{O} 26 \mathrm{O}$-antigen moiety of the lipopolysaccharide of enterohemorrhagic Escherichia coli strain 4276 Clin Diagn Lab Immunol 2004, 11:532-537.

38. Bardiau M, Labrozzo S, Mainil JG: Putative adhesins of enteropathogenic (EPEC) and enterohemorrhagic (EHEC) Escherichia coli of serogroup 026 isolated from humans and cattle. J Clin Microbiol 2009.

39. China B, Pirson V, Mainil J: Typing of bovine attaching and effacing Escherichia coli by multiplex in vitro amplification of virulenceassociated genes. Appl Environ Microbiol 1996, 62:3462-3465.

40. Fagan PK, Hornitzky MA, Bettelheim KA, Djordjevic SP: Detection of shigalike toxin (stx1 and st $\times 2$ ), intimin (eaeA), and enterohemorrhagic Escherichia coli (EHEC) hemolysin (EHEC hlyA) genes in animal feces by multiplex PCR. Appl Environ Microbiol 1999, 65:868-872.

41. Durso LM, Bono JL, Keen JE: Molecular serotyping of Escherichia coli O26: H11. Appl Environ Microbiol 2005, 71:4941-4944.

doi:10.1186/1471-2180-11-124

Cite this article as: Bardiau et al: Study of polymorphisms in tir, eae and tccP2 genes in enterohaemorrhagic and enteropathogenic Escherichia coli of serogroup O26. BMC Microbiology 2011 11:124.

\section{Submit your next manuscript to BioMed Central} and take full advantage of:

- Convenient online submission

- Thorough peer review

- No space constraints or color figure charges

- Immediate publication on acceptance

- Inclusion in PubMed, CAS, Scopus and Google Scholar

- Research which is freely available for redistribution

Submit your manuscript at www.biomedcentral.com/submit
Biomed Central 